\title{
RATIO LEGIS TIDAK ADANYA PENGATURAN UPAYA HUKUM DARI DEPONERING YANG DIKELUARKAN OLEH JAKSA AGUNG
}

\author{
Aris Mustriadhi \\ Program PascaSarjana Universitas Brawijaya Malang \\ Jalan MT. Haryono No 169 Malang, Jawa Timur \\ Email : arismustriadhi@gmail.com
}

\begin{abstract}
Deponering is one of the authorities which is only owned bye the attorney general or known as the cases for the sake of public interest. The nature of this deponering is final without legal remedies. This paper aims to analyze the legis ratio and the legal implications of the lack of regulations regarding the restoration of deponering law issued by the attorney general based on the principle of check and balance of state law and also the principle of equality before the law.To answer the problems in this paper, normative legal research is used by using a legal approach and conceptual approach. The results of the study in this paper show that the legis ratio of the absence of regulation releated to legal efforts is on the basis of the implementation of the princple of opportuity and the legal implications of the lack of regulation regarding the legal remedies of the deponering have led to the failure of pinciple of check and balance and the non-enactment of the princeple of equality before the law. Because the deponering authority by the attorney general is final and has no legal remedies
\end{abstract}

Key words: Legal Effort, Deponering, Public Interest

\begin{abstract}
ABSTRAK
Deponering adalah suatu wewenang yang hanya dimilikii oleh jaksa agung atau dikenal dengan penyampingaan perkara demi kepentingan umum. Sifat keputusan deponering ini ialah final tanpa adanya upaya hukum. Tulisan ini bertujuan untuk menganalisis ratio legis dan implikasi hukum tidak adanya pengaturan mengenai upaya hukum dari Deponering yang dikeluarkan oleh jaksa agung berdasarkan prinsip check and balance negara hukum dan juga asas equality before the law. Untuk menjawab permasalahan dalam tulisan ini, digunakan penelitian hukum normatif dengan menggunakan pendekatan undang-undang dan pendekatan konseptual. Hasil penelitian dalam tulisan ini menunjukan bahwa ratio legis tidak adanya pengaturan terkait dengan upaya hukum ialah atas dasar pelaksaan asas opportunitas dan implikasi hukum tidak adanya pengaturan mengenai upaya hukum dari Deponering ini menimbulkan tidak berjalannya prinsip check and balance dan tidak berlakunya asas Equality Before The Law. Karena kewenangan Deponering oleh jaksa agung bersifat final dan tidak memiliki upaya hukum
\end{abstract}

Kata Kunci: Upaya Hukum, Deponering, Kepentingan Umum

\section{PENDAHULUAN}

Indonesia mempunyai kedudukan rechtstaat (negara hukum) ${ }^{1}$ pengertian dalam Konstitusi sebagai dasar negara, Indonesia didirikan berdasarkan atas hukum (rechtstaat). Hal tersebut bertujuan untuk memberikan suatu pedoman bagi warga negara dalam menghormati Hak dan Kewajiban antar masyarakat agar terciptanya suatu kondisi yang kondusif dalam

$1 \quad$ Isi Pasal 1 ayat 3 Undang-undang Dasar Negara Republik Indonesia Tahun 1945. 
bermasyarakat.

Penyelenggaran negara haruslah berdasarkan pada ketentuan sebuah hukum yang berlaku dan bukan berdasarkan kekuasaan semata (mactstaat) maka dari itu dalam penyelenggaran negara wajib menjunjung Supremasi hukum. Bentuk penyelengaraan berdasarkan supremasi hukum yang mengatur tentang kewenangan Jaksa dalam melakukan Penututan menurut KUHAP "adalah tindakan penuntut umum untuk melimpahkan perkara pidana ke pengadilan negeri yang berwenang dalam hal dan menurut cara yang diatur dalam undangundang ini dengan permintaan supaya diperiksa dan diputus oleh hakim di sidang pengadilan". ${ }^{2}$ Dan hal itu harus berjalan dan berlaku diberbagai cabang-cabang kebijakan Negara lainnya.

Kewenangan lain di bidang penuntutan tidak hanya diatur dalam KUHAP tetapi di atur juga dalam UU Kejaksaan Republik Indonesia $^{3}$ kewenangan tersebut adalah Deponering. Deponering dikenal dengan penyampingan perkara demi kepentingan umum merupakan salah satu wewenang yang diberikan oleh UU terhadap jaksa dalam hal ini Jaksa Agung.

Kewenangan Khusus bagi Jaksa Agung diatur pada pasal 35 Undang-undang Nomor 16 tahun 2004 Tentang Kejaksaan Republik
Indonesia antara lain:

a. Menetapkan serta mengendalikan kebijakan penegakan hukum dan keadilan dalam ruang lingkup tugas dan wewenang kejaksaan;

b. Mengefektifkan proses penegakan hukum yang diberikan oleh undang-undang;

c. Mengesampingkan perkara demi kepentingan umum;

d. Mengajukan kasasi demi kepentingan hukum kepada Mahkamah Agung dalam perkara pidana, perdata, dan tata usaha negara;

e. Dapat mengajukan pertimbangan teknis hukum kepada Mahkamah Agung dalam pemeriksaan kasasi perkara pidana;

f. Mencegah atau menangkal orang tertentu untuk masuk atau keluar wilayah Negara Kesatuan Republik Indonesia karena keterlibatannya dalam perkara pidana sesuai dengan peraturan perundang-undangan.

Ketentuan dalam aturan Kejaksaan Republik Indonesia menjelaskan bahwa "Deponering adalah tugas dan wewenang yang diberikan secara khusus untuk Jaksa Agung dalam menyampingkan perkara demi kepentingan umum". Dalam penjelasan pada pasal 35 huruf c tersebut dijelaskan:

"bahwa yang dimaksud kepentingan umum adalah kepentingan bangsa dan negara dan/atau kepentingan masyarakat luas". ${ }^{4}$

\footnotetext{
Isi Pasal 1 angka 7 Undang-undang Nomor 8 Tahun 1981 Tentang KUHAP.

Undang-undang Nomor 16 Tahun 2004 Tentang Kejaksaan Republik Indonesia.

4 Bagian Penjelasan Pasal 35 huruf C Undang-Undang 16 Tahun 2004 Tentang Kejaksaan Republik Indonesia.
} 
Kasus yang disebutkan dalam ketentuan ini adalah penerapan asas opportunitas, yang hanya dapat dilakukan Jaksa Agung berdasarkan posisinya (ambtshalve), setelah menerima advice and accept lembaga negara yang kompeten, memiliki hubungan dengan masalah tersebut. Walaupun perkara sudah cukup bukti dan fakta ini sengaja dikesampingkan dan tidak delegasikan kepengadilan karena Jaksa Agung berpendapat bahwa dengan mengklaim suatu kasus, kepentingan publik akan mengurangi lebih banyak kerugian daripada tidak menuntutnya. ${ }^{5}$

Contoh kasus perkara pidana yang pernah di Deponering oleh Jaksa Agung adalah kasus Chandra M Hamzah dan Bibit S Riyanto atau yang sering kita kenal dengan kasus Bibit Chandra yang terjadi ada tahun 2009, mereka adalah mantan pemimpin Komisi Pemberantasan Korupsi (KPK) pada masa pemerintahan Susilo Bambang Yudhoyono dan Jaksa Agung yang mengeluarkan Deponering ialah Basrief Arief. Kasus bermula saat Antasari membuat testimoni tentang penerimaan uang sebesar $\mathrm{Rp}$ 6,7 miliar oleh sejumlah pimpinan KPK pada 16 mei 2009. Padaa saat itu Antasari sedang ditahan atas kasus dugaan pembunuhan Direktur PT Putra Rajawali Banjaran Nasrudin Zulkarnaen. Karena testimoni tidak ditindaklanjuti polisi, Antasari lalu membuat laporan resmi pada 6 Juli 2009 mengenai dugaan suap itu di Polda Metro Jaya. Kemudian laporan itu dilimpahkan ke Mabes Polri, lalu dilanjutkan ke penyelidikan dan penyidikan. Dalam proses lidik dan sidik, kata Kapolri, pada 7 Agustus 2009 diperoleh fakta adanya tindak pidana penyalahgunaan wewenang oleh dua tersangka yang melanggar Pasal 21 Ayat 5 UU No 30 Tahun 2002 tentang KPK. Saat penyidikan, ditemukan keputusan pencekalan dan pencabutan pencekalan yang dilakukan oleh kedua tersangka tidak secara kolektif. Pencekalan terhadap Anggoro Widjojo dilakukan oleh Chandra Hamzah, pencekalan terhadap Joko Tjandra oleh Bibit S Riyanto, serta pencabutan pencekalan terhadap Joko Tjandra oleh Chandra Hamzah. Kemudian, dari hasil penyidikan kasus pencekalan terhadap Anggoro ditemukan adanya aliran dana. Temuan itu kemudian dituangkan dalam laporan polisi pada 25 Agustus 2009. Dalam kasus dugaan pemerasan, penyidik telah melakukan pemeriksaan terhadap saksi-saksi dan alat bukti lain. Sedangkan sangkaan penyalahgunaan wewenang, penyidik telah memeriksa sebanyak 22 saksi serta saksi ahli dan ditemukan beberapa dokumen. Pasal yang disangkakan adalah Pasal 23 UU No 31 Tahun 1999 Jo Pasal 421. Dari alat bukti, keterangan saksi, dan saksi ahli didapat empat alat bukti. 
Lalu pada tanggal 15 September 2009 pukul 23.20, dua pimpinan KPK nonaktif itu ditingkatkan statusnya dari saksi menjadi tersangka. Pada 2 Oktober 2009, berkas perkara Chandra Hamzah dikirimkan ke Kejaksaan dan berkas Bibit S Riyanto dikirimkan pada 9 Oktober. Kemudian, penyidik melakukan penahanan pada 29 Oktober 2009 karena kedua tersangka melakukan tindakan mempersulit jalannya pemeriksaan dengan menggiring opini publik melalui pernyataan-pernyataan di media serta forum diskusi. ${ }^{6}$

Keputusan deponering yang dimiliki oleh jaksa agung bersifat final tidak memiliki upaya hukum, walaupun sampai saat ini belum dijelaskan Deponering demi kepentingan umum yang dimaksud. Sehingga dengan adanya Deponering ini, menyebabkan adanya perbedaan perlakuan dihadapan hukum dan tidak sesuai dengan salah satu asas negara hukum ${ }^{7}$ yang dianut oleh negara Indonesia. serta tidak adanya bentuk upaya perlawanan hukum yang dapat dilakukan dengan dikeluarkannya deponering ini yang dikhawatirkan terjadinya penyalahgunaan wewenang oleh Jaksa Agung dan tidak berjalannya prinsip check and balance antara eksekutif dengan yudikatif.

Serta Keputusan suatu perkara di Deponering sebagai Tugas dan Wewenang yang dimiliki Jaksa Agung memiliki makna dalam suatu Keputusan yang jika dilihat dalam definisi KTUN dalam pasal 1 angka 9 Undang-undang Nomor 51 tahun 2009 Tentang Perubahan Kedua Atas Undangundang Nomor 5 Tahun 1986 Tentang Pengadilan Tata Usaha Negara berbunyi :

"Keputusan Tata Usaha Negara adalah suatu penetapan tertulis yang dikeluarkan oleh badan atau pejabat tata usaha negara yang berisi tindakan hukum tata usaha negara yang berdasarkan peraturan perundangundangan yang berlaku, yang bersifat konkret, individual, dan final, yang menimbulkan akibat hukum bagi seseorang atau badan hukum perdata"

Seharusnya apabila keputusan Deponering masuk dalam definisi Keputusan Tata Usaha Negara dapat dilakukan Gugatan ke PTUN karena dalam Undang-undang PTUN itu sendiri menyatakan apabila suatu keputusan dapat dibatalkan melalui gugatan yang ditujukan kepada Pengadilan Tata Usaha Negara.

Namun pada pasal 2 huruf D undangundang 5 Tahun 1986 Tentang Peradilan Tata Usaha Negara menjelaskan:

"Tidak termasuk dalam pengertian Keputusan Tata Usaha Negara menurut undang-undang ini ialah Keputusan Tata Usaha Negara yang dikeluarkan berdasarkan ketentuan Kitab Undang-undang Hukum Pidana atau Kitab Undang-undang Hukum Acara Pidana atau peraturan perundangundangan lain yang bersifat hukum pidana"

\footnotetext{
6 https://nasional.kompas.com/read/2009/10/30/20562153/inilah.kronologi.kasus.penyidikan. kasus.chandra.dan.bibit diakses pada tanggal 15 Januari 2019 Pukul 16.00 WIB

7 Asas Tersebut adalah "Equality Before the Law"
} 
Hal itulah yang menjadi point bahwa deponering tidak termasuk objek KTUN. Namun, materiil substansial di dalam Undang-undang Kejaksaan Republik Indonesia tersebut tidak ada penjelasan tentang kriteria apa suatu subjek yang terlibat perkara pidana sehingga perkara tersebut harus dikesampingkan. Dari Pasal di atas, kekaburan dari makna kepentingan umum yang dimaksud belum jelas. Penjelasan mengenai kepentingan umum dalam pasal itu dibutuhkan untuk mencegah ketidakpastian hukum dan karena makna dari kepentingan umum ini masih bersifat luas dan tidak spesifik.

Keputusan deponering yang merupakan keputusan Final dan mengikat tanpa banding inilah yang dianggap sama dengan penegakan keadilan tanpa pengadilan, karena dalam kasus ini, kebebasan penegakan hukum adalah Jaksa Agung, yang secara individu menafsirkan keadilan, meskipun semua ini berada dalam kerangka hukum yang berlaku hal ini juga menjadi suatu kekosongan aturan karena pada penjelasan dalam Undangundang tersebut belum adanya upaya hukum untuk mencabut Deponering, karena pencabutan kasus-kasus kepentingan umum hanya dimungkinkan jika Jaksa Agung mencabutnya dengan ketentuan baru yang membatalkan ketentuan sebelumnya. Serta dalam sistem peradilan di Indonesia yang tidak memberikan ruang mengenai prosedur pengajuan keberatan dalam keputusan Deponering yang dikeluarkan oleh Jaksa Agung

Atas penjelasan latar belakang tersebut maka ditarik suatu masalah Apa Ratio Legis tidak adanya pengaturan mengenai Upaya Hukum dari Deponering yang dikeluarkan oleh Jaksa Agung? Apa implikasi hukum tidak adanya pengaturan mengenai Upaya Hukum dari Deponering yang dikeluarkan oleh Jaksa Agung?

Metode penelitian yang akan dilakukan pada jurnal ini ialah penelitian normatif. ${ }^{8}$ Yang dilakukan melalui penelitian kepustakaan. Penelusuran bahan hukum dalam penelitian ini terdiri dari bahan hukum primer dan bahan hukum sekunder. Pendekatan penelitian ini akan dilakukan melalui pendekatan terhadap salah satu peraturan perundangan-undangan di Indonesia khususnya Undang-undang Kejaksaan Republik Indonesia dan Undang-undang Nomor 8 Tahun 1981 Tentang Kitab Undangundang Hukum Acara Pidana (KUHAP) serta pendekatan konseptual yaitu pendekatan dengan merujuk dari pandangan-pandangan sarjana dan doktrin-dokrtin yang berkembang dalam ilmu hukum.

\section{PEMBAHASAN \\ Ratio Legis tidak adanya pengaturan mengenai Upaya Hukum dari Deponering}

\footnotetext{
8 Marzuki Mahmud Peter, (2014), Penelitian Hukum, Jakarta; Kencana Prenada Media Group, hlm 47
} 
yang dikeluarkan oleh Jaksa Agung

Deponering atau yang lebi dikenal dengan penyampingan perkara demi kepentingan umum merupakan salah satu wewenang yang diberikan oleh Undang-undang terhadap jaksa dalam hal ini Jaksa Agung. Ketentuan dalam aturan Kejaksaan Republik Indonesia menjelaskan bahwa "Deponering adalah tugas dan wewenang yang diberikan secara khusus untuk Jaksa Agung dalam menyampingkan perkara demi kepentingan umum". Dalam penjelasan pada pasal tersebut dijelaskan:

"bahwa yang dimaksud kepentingan umum adalah kepentingan bangsa dan negara dan/atau kepentingan masyarakat luas". 9

Menyangkut mengenai Deponering yang menjadi kewenangan Jaksa Agung sudah ada semenjak Undang-undang tentang Kejaksaan pertama kali disahkan, yaitu pada pasal (8) Undamg-undang Nomor 15 Tahun 1961 Tentang Ketentuan-Ketentuan Pokok Kejaksaan Republik Indonesia yang berbunyi "Jaksa Agung dapat mengenyampingkan perkara demi kepentingan umum". ${ }^{10}$

Mengenai tidak adanya pengaturan mengenai upaya hukum dari Deponering yang dikeluarkan oleh Jaksa Agung jika dilihat dari awal pembentukan Undangundang kejaksaan pada tahun 1961 yaitu
Undang-undang Nomor 15 Tahun 1961 Tentang Ketentuan-Ketentuan Pokok Kejaksaan Republik Indonesia, Undangundang Nomor 5 Tahun 1991 Tentang Kejaksaan Republik Indonesia, dan Undangundang Nomor 16 Tahun 2004 tentang Kejaksaan Republik Indonesia hanya sebatas aturan yang mengatur pengenyampingan perkara demi kepentingan umum, namun tidak menjelaskan upaya hukum yang dapat di tempuh dengan dikeluarkannya pengenyampingan perkara demi kepentingan umum (deponering). Dalam buku yang ditulis Yusril Ihza Mahendra, O.C. Kaligis bahkan menuturkan bahwa bukanlah suatu hal yang mustahil apabila di kemudian hari ketetapan pengesampingan perkara pidana ini dapat digugat di muka Pengadilan, untuk mempertanyakan apakah dalam menjalankan kewenangannya tersebut, Jaksa Agung memiliki alasan yang kuat dan cukup, bahwa syarat demi kepentingan umum yang dijadikan sebagai tolok ukur, telah terpenuhi dan merepresentasikan kepentingan bangsa dan negara dan/atau kepentingan masyarakat yang luas ${ }^{11}$.

Kasus yang disebutkan dalam ketentuan diatas adalah penerapan asas opportunitas, yang hanya dapat dilakukan Jaksa Agung berdasarkan posisinya (ambtshalve), setelah

\footnotetext{
9 Bagian Penjelasan Pasal 35 huruf C Undang-Undang 16 Tahun 2004 Tentang Kejaksaan Republik Indonesia.

10 Pasal 8 Undamg-undang Nomor 15 Tahun 1961 Tentang Ketentuan-Ketentuan Pokok Kejaksaan Republik Indonesia.

11 Kaligis O.C., (2011), Deponering, Teori dan Praktik, Edisi. Pertama Cetakan ke-1, Bandung; PT. Alumni, hlm. 5.
} 
menerima advice and accept lembaga negara yang kompeten, memiliki hubungan dengan masalah tersebut. Walaupun perkara sudah cukup bukti dan fakta ini sengaja dikesampingkan dan tidak delegasikan kepengadilan karena Jaksa Agung berpendapat bahwa dengan mengklaim suatu kasus, kepentingan publik akan mengurangi lebih banyak kerugian daripada tidak menuntutnya. ${ }^{12}$

Prinsip dasar dari implementasi asas oportunitas berupa pengesampingan perkara pidana demi kepentingan umum yang menjadi wewenang Jaksa Agung ini menutup peluang adanya praperadilan dan pemeriksaan berikutnya kendati dengan alasan hukum seperti adanya bukti yang baru dan sebagainya. ${ }^{13}$ Asas tersebut meniadakan penuntutan hukum berdasarkan pertimbangan bahwa lebih menguntungkan kepentingan umum jikalau tidak diadakan penuntutan dibanding harus melakukan penuntutan atas suatu perkara pidana. Van Apeldoorn menuturkan bahwa salah satu kelebihan dari adanya asas opportunitas ini memang semestinya penegakan hukum (pidana) itu ultimum remedium (pidana sebagai upaya terakhir) bukan sebagai primum remedium (pidana sebagai pilihan utaama). Terlebih lagi untuk masalah yang sebenarnya dapat diselesaikan melalui pendekatan non-litigasi. penegak hukum selayaknya tidak terlampau mudah menuntut secara pidana seseorang atas tindakannya. $^{14}$

Kewenangan untuk tidak menuntut atas pertimbangan kepentingan umum, dikarenakan lebih banyak mudaratnya daripada manfaatnya bagi kemaslahatan masyarakat. Tindakan yang diambil Jaksa Agung tersebut sebenarnya merupakan tindakan diskresi di bidang penuntutan. Prof. Dr. Mr. Prajudi Atmosudirdjo menterjemahkan discretion (Inggris) discretion (Perancis) dan freies ermessen (Jerman) "sebagai kebebasan bertindak" atau mengambil keputusan menurut "pendapat sendiri”. A.F.Wilcox dalam bukunya The Decision to Prosecute (London) Butter Worths 1972 menyatakan bahwa "Discretion means the freedom to break rules", karena tidak ada satu pun yang dapat atau mampu merumuskan rules fettering discretion. ${ }^{15}$

Dalam Rancangan Undang-undang Nomor 15 Tahun 1961 Tentang Ketentuan-Ketentuan Pokok Kejaksaan Republik Indonesia Pasal 9 menyebutkan "Djaksa Agung dapat menjampingkansuatu perkara berdasarkan kepentingan umum". ${ }^{16}$ kewenangan terkait

12 Nasution Karim, (2004), Dengar Pendapat Komisi III Dewan Perwakilan Rakyat Mengenai Masalah Hukum Acara Pidana, Jakarta, hlm 36.

13 Amiati Mia, (2014), Memaknain Kepentingan Umum Dalam Oportunitas Jaksa Agung (Tinjauan Perspektif Teoretis), Jakarta; Miswar, hlm. 5.

14 Ibid, hlm. 12.

15 Prakoso Djoko, (1985), Eksistensi Jaksa di Tengah-tengah Masyarakat, Jakarta; Ghlmia Indonesia, hlm. 102.

16 Risalah RUU Tentang Ketentuan-Ketentuan Pokok Kejaksaan Republik Indonesia tahun 1961, hlm. 4. 
dengan pengenyampingan perkara demi ditandatangani oleh Presiden Soekarno pada kepentingan umum dalam bagian UMUM tanggal 30 Juni 1961 menjadi UU No.15 menjelaskan "Berhubung dengan tugas Tahun 1961 (LN No. 254) dengan Penjelasan Kedjaksaan sebagai jang dilukiskan diatas (TLN No. 2298) dengan rumusan pasal perlu diperhatikan": mengenai pengesampingan perkara demi

(1) Wewenang-wewenang jang dapat diselenggarakan hanja oleh Menteri/Djaksa Agung, sebagai Menteri jang memimpin suatu Departemen dan atau sebagai DjaksaAgung.

Dalam hubungan ini dapat disebut antara lain:

a. memberi petundjuk-petundjuk untuk kepentingan penuntutan perkara kepada para penjidik dan penuntut;

b. menjampingken perkara berdasarkan kepentingan umum;

c. mengawasi sahnja penahanan orang oleh pedjabat-pedjabat Kedjaksaan ${ }^{17}$

Sedangkan dalam penjelasan PASAL DEMI PASAL pada pasal 9 berisi:

"Ditekankan dalam pasal ini bahwa dilingkungan Kedjaksaan hanja Djaksa Agunglah jang mempunyai hak menjampingkan suatu perkara berdasarkan kepentingan umum. Selandjutnja sekalipun tidak ditegaskan dalam pasal 9, namun dimengerti bahwa sesuai dengan praktek berlaku proseduro bahwa dalam suatu perkara jang serba penting Djaksa Agung sebelum mengambil tindakan penjampingan perkara itu, berunding dulu dengan Menteri/Kepala Kepolisian Negara". ${ }^{18}$

RUU ini kemudian disahkan dan

kepentingan umum sebagai berikut:

Pada pasal 8 berbunyi : "Djaksa Agung dapat menjampingkan suatu perkara berdasarkan kepentingan umum. Penjelasan Pasal Demi Pasal" sedangkan penjelasan pada pasal 8 ialah : "Ditekankan dalam pasal ini, bahwa dilingkungan Kedjaksaan, Djaksa Agung jang mempunjai hak menjampingkan suatu perkara berdasarkan kepentingan umum. Selandjutnja sekalipun tidak ditegaskan dalam pasal ini, namun dimengerti bahwa sudah mendjadii kebiasaan dalam praktek selama ini, bahwa dalam menjampingkan perkara jang menyangkut kepentingan umum, Djaksa Agung senantiasa bermusjawarah dengan pedjabat-pedjabat tertinggi jang ada sangkut pautnja dalam perkara tersebut misalnja antara lain: Menteri/Kepala Kepolisian Negara, Menteri Keamanan Nasional, bahkan djuga sering kali langsung kepada Presiden/Perdana Menteri."

Sebelumnya Rancangan Undang-undang ini tidak memiliki hambatan yang berarti sebelum pegesahan, pasal 8 pada Undangundang Nomor 15 Tahun 1961 Tentang

17 Bagian umum Risalah RUU Tentang Ketentuan-Ketentuan Pokok Kejaksaan Republik Indonesia tahun 1961, hlm. 1.

18 Pasal Demi Pasal Risalah RUU Tentang Ketentuan-Ketentuan Pokok Kejaksaan Republik Indonesia tahun 1961, hlm. 5. 
Ketentuan-Ketentuan Pokok Kejaksaan Republik Indonesia yang mengatur tentang pengenyampingan perkara demi kepentingan umum, karena jika dilihat dan disimpulkan adanya pengenyampingan perkara ini hanya untuk menjalakan Asas Oportunitas yang dimiliki oleh Jaksa Agung, dan wewenang Djaksa Agung tentang penjampingan perkara untuk kepentingan umum (pasal 8).

Sedangkan perubahan kedua atas Undangundang kejaksaan terjadi pada tahun 1991, dimana lahirlah Undang-undang Nomor 5 Tahun 1991 Tentang Kejaksaan Republik Indonesia yang sebenarnya pembahasan mengenai pengaturan pengenyampingan perkara demi kepentingan umum tidak dibahas secara eksplisit karena dalam pembahasan tersebut hanya menentukan kriteria kepentingan umum, yang pada akhirnya munculan frasa "kepentingan bangsa, dan negara, dan/atau masyarakat luas". ${ }^{19}$ Pengaturan mengenai pengesampingan perkara demi kepentingan umum diatur dalam Pasal 32 huruf c pada bagian wewenang khusus yang dimiliki oleh Jaksa Agung. Yang dimana penjelasan pasal demi pasal dalam Undang-undang tersebut;

$\begin{array}{lr}\text { "Yang dimaksud } & \text { dengan } \\ \text { "kepentingan umum" adalah } & \text { umuan } \\ \text { kepentingan bangsa dan negara dan atau } \\ \text { kepentingan masyarakat ruas, } \\ \text { mengenyampingkan } & \text { perkara } \\ \text { sebagaimana dimaksud dalam ketentuan }\end{array}$

ini merupakan pelaksanaan asas opportunitas, hanya dapat dilakukan oleh Jaksa Agung setelah memperhatikan saran dan pendapat dari badan-badan kekuasaan negara yang mempunyai hubungan dengan masalah tersebut. Sesuai dengan sifat dan bobot perkara yang dikesampingkan tersebut, Jaksa Agung dapat melaporkan terlebih dahulu rencana pengeyampingan perkara kepada Presiden, untuk mendapatkan petunjuk. ${ }^{20}$

Kemudian perubahan terakhir terjadi pada tahun 2004, dimana Undang undang Nomor 16 Tahun 2004 Tentang Kejaksaan Republik Indonesia ini masih berlaku hingga sekarang. Namun perubahan tersebut juga tidak membahas mengenai upaya hukum terhadap deponering, fokus perubahan dalam Undangundang ini hanya terkait pasal pengenyampingan perkara demi kepentingan umum dan juga penghapusan frasa "Sesuai dengan sifat dan bobot perkara yang dikesampingkan tersebut, Jaksa Agung dapat melaporkan terlebih dahulu rencana pengeyampingan perkara kepada Presiden, untuk mendapatkan petunjuk"21

Berdasarkan uraian yang didapat dari 3 risalah sidang pembahasan Undang-Undang tentang Kejaksaan di atas, yaitu risalah sidang pembahasan Undang-Undang Nomor 15 Tahun 1961 tentang Ketentuan-ketentuan Pokok Kejaksaan Republik Indonesia, Undang-undang Nomor 5 Tahun 1991 Tentang Kejaksaan Republik Indonesia, dan

\footnotetext{
19 Risalah RUU tentang Kejaksaan Republik Indonesia tahun 1991.

20 Ibid.

21 Risalah RUU tentang Kejaksaan Republik Indonesia tahun 2004.
} 
Undang-undang Nomor 16 Tahun 2004 tentang Kejaksaan Republik Indonesia, pada prinsipnya tidak ditemukan secara jelas mengenai latar belakang pengaturan mengenai upaya hukum yang dapat dilakukan dengan dikeluarkannya Deponering atau pengenyampingan perkara demi kepentingan umum karena ketentuan ini sebenarnya belum pernah ternuat dalam salah satu pasal dari Perundang-undangan dahulu sampai sekarang ini. Hak-hak demikian ini dari dahulu hanya merupakan theorye dari ahli-ahli hukum saja dan tidak pernah dikodifikasi. Karena Ketentuan ini pada zaman colonial belanda dipergunakan oleh kaum pendjadjah sendiri, agar tidak terkena penuntutan terhadapnya, apabila dia memperbuat kesalahan terhadap peraturan kolonial yang dibuatnya sendiri.

Hal inilah jika dilihat menjadi suatu kekuarangan dari adanya Asas Oportunitas, dikhawatirkan apabila tidak ada pembatasan atas adanya Deponering yang dikeluarkan oleh Jaksa Agung akan cenderung menyalahgunakan kewenangannya dalam mengenyampingkan perkara demi kepentingan umum, Karena sudah sangat jelas apabila suatu kewenangan tidak dibatasi akan cenderung menyimpang, mengutip pendapat Lord Acton "Power tends to corrupt absolute power tends to corrupt absolutely (manusia yang memiliki kekuasaan akan cenderung untuk menyalahgunakannya, akan tetapi manusia manusia yang mempunyai kekuasaan absolut sudah pasti akan menyalahgunakannya”. Dengan demikian, pengawasan terhadap suatu kekuasaan merupakan syarat utama berjalannya sistem demokrasi yang baik dalam suatu negara. Pengawasan terhadap penyelenggaran pemerintahan tersebut dapat dilakukan melalui pengawasan secara dalam pengawasan masyarakat, dan pengawasan secara fungsional.

\section{Implikasi hukum tidak adanya pengaturan} mengenai Upaya Hukum dari Deponering yang dikeluarkan oleh Jaksa Agung

Implikasi hukum dengan dikeluarkannya Deponering yang menjadi yurisdiksi kejaksaan yang dalam hal ini Jaksa Agung telah menjadii kekuasaan yang sangat penting dalam mengyampingkan perkara pidana yang sudah jelas nilai pembuktiannya. Jaksa Agung yang berwenang menyampingkan perkara (deponering) harus menafsirkan apa itu kepentingan umum dengan cermat dan sesuai dengan maksud dan tujuan dari adanya Deponering tersebut. Mengingat dalam penjelasan Pasal 35 (c) Undang-undang Nomor 16 Tahun 2004 Tentang Kejaksaan Republik Indonesia hanya menjelaskan kepentingan umum ialah kepentingan negara, bangsa, atau masyarakat. Jaksa Agung harus teliti dan berhati-hati dalam melakukan wewenang ini, karena ada kemungkinan dengan memakai kepentingan Negara, kepentingan Bangsa, atau kepentingan masyarakat luas sebagai alasan seorang Jaksa Agung menyampingkan perkara pidana, 
namun hal tersebut juga dapat dilakukan untuk kepentingan pribadi atau golongan atau kelompok tertentu, yang dalam hal ini tentu bertentangan dengan tujuan dari penyampingan perkara (deponering) bila tidak adanya kontrol dari penggunaan Asas Opportunitas tersebut.

Penulis beranggapan ketentuan dari Pasal 35 (c) Undang-undang Nomor 16 Tahun 2004 Tentang Kejaksaan Republik Indonesia kurang jelas dan berimplikasi terhadap Jaksa Agung sebagai satu satunya lembaga yang memiliki kewenangan menyampingkan perkara tersebut. Dalam penggunaan Deponering timbul penafsiran yang beragam dan perbedaan pendapat dari lembaga negara lain dan masyarakat pada umumnya. Hal ini tentu sangat tidak baik karena dapat mengganggu keharmonisan antara lembaga negara ditambah lagi dalam penggunaan Deponering tidak memiliki kontrol dan juga upaya hukum yang dapat ditempuh denga dikeluarkannya Deponering oleh Jaksa Agung.

Hal ini menyebabkan perlu diatur lebih jelas sejauh mana batasan-batasan yangg menjadi ukuran apa itu kepentingan negara, kepentingan bangsa, atau kepentingan masyarakat. Agar dalam menggunakan kewenangan menyampingkan perkara ini mencerminkan kepastian, kemanfaatan dan keadilan. Kemudian tidak terjadi salah tafsir oleh Jaksa Agung dalam merumuskan kepentingan umum dan juga kontrol atau pengawasan terhadap penggunaan Deponering yang hanya dimiliki oleh Jaksa Agung ini agar tidak terjadinya penyalahgunaan wewenang yang hanya dimiliki oleh Jaksa Agung.

Menurut Saiful Anwar, pengawasan atau kontrol ialah suatu tindakan aparatur pemerintah yang diperlukan agar pelaksanaan tugas yang telah ditetapkan dapat mencapai tujuan dan terhindar dari penyimpanganpenyimpangan. Dimana tujuan pengawasan itu sendiri berarti untuk mengontrol penegakan hukum di bidang penuntutan dan memastikan telah berjalan sesuai dengan peraturan perundang-undangan yang berlaku.

Sedangkan menurut M. Manullang mengatakan bahwa, pengawasan adalah suatu proses untuk menetapkan suatu pekerjaan apa yang sudah dilaksanakan, menilainya dan mengoreksi bila perlu dengan maksud supaya pelaksanaan pekerjaan sesuai dengan rencana semula. $^{22}$

Pengawasan yang dilakukan bertujuan untuk mendukung kelancaran pelaksanaan kegiatan sehingga dapat terwujud daya guna, hasil guna, dan tepat guna sesuai rencana dan sejalan dengan itu, untuk mencegah secara dini kesalahan-kesalahan dalam pelaksanaan. Sedangkan tujuan dari pengawasan akan tercapai apabila hasil-hasil pengawasan

22 Manullang. M, (1995), Dasar-Dasar Manajemen, Jakarta; Ghlm.ia Indonesia, hlm 18. 
maupun memperluas dasar untuk terhadap kekuasaan yang lain. Dengan pengambilan keputusan setiap pimpinan. demikian kekuasaan harus saling Hasil pengawasan juga dapat digunakan mengimbangi.

sebagai dasar untuk penyempurnaan rencana kegiatan rutin dan rencana berikutnya. Pada dasarnya pengawasan bertujuan untuk mengoreksi kesalahan-kesalahan yang terjadi nantinya dapat digunakan sebagai pedoman untuk mengambil kebijakan guna mencapai sasaran yang optimal.

Pengawasan sangatlah diperlukan untuk menjaga agar pelaksanaan kegiatan penegakan hukum berjalan sesuai dengan perencanaan dan sesuai dengan ketentuan peraturan yang berlaku. Perencanaan tersebut dapat diartikan sebagai fungsi manajemen yang menentukan strategi terbaik dan taktik untuk mencapai tujuan dan target dalam organisasi. Selain itu, dalam rangka mewujudkan pemerintahan yang baik dan juga pemerintahan yang bersih dari tindakantindakan yang tidak diinginkan, pengawasan juga diperlukan untuk mendukung penyelenggaraan pemerintahan yang efektif dan efisien, transparan, filterisasi, serta bersih dan bebas dari praktik-praktik kekuaasan yang absolut.

Hakikat dari pemisahan kekuasaan yang dianut di Indonesia sendiri agar tidak terjadi pemusatan kekuasaan. Seperti yang dinyatakan oleh montesquie bahwa dengan memisahkan fungsi eksekutif, legislatif, dan yudikatif maka satu cabang kekuasaan yang satu dapat beroperasi sebagai keseimbangan

Pemisahan atau pembagian kekuasaan juga terkait erat dengan independensi peradilan. Prinsip pemisahan kekuasaan (separation of powers) itu menghendaki bahwa para hakim dapat bekerja secara independen dari pengaruh kekuasaan eksekutif dan legislatif. Bahkan, dalam memahami dan menafsirkan undang-undang dasar dan undang-undang, hakim harus independen dari pendapat dan bahkan dari kehendak politik para perumusan undang-undang dasar dan undang-undang itu sendiri ketika perumusan dilakukan. Walaupun anggota parlemen dan presiden yang dipilih langsung oleh rakyat mencerminkan kedaulatan rakyat dalam menentukan kebijakan kenegaraan, tetapi kata akhir dalam memahami maksudnya tetap berada di tangan para hakim.

Pada lingkungan Kejaksaan Agung Republik Indonesia penerapan dibidang penuntutan yang menjadi wewenang kejaksaan harus adanya pengawasan, tujuannya agar tidak terjadinya penyalahgunaan wewenang dari pelaksanaan tugas tersebut khususnya pengenyampingan perkara demi kepentingan umum yang diatur dalam pasal 35 huruf c Undang-undang Nomor 16 Tahun 2004 yang menjadi wewenang Jaksa Agung. Pengawasan sendiri merupakan suatu tindakan yang pada dasarnya diarahkan sepenuhnya untuk menghindari 
adanya kemungkinan penyelewengan atau penyimpangan atas tujuan yang akan dicapai. Melalui pengawasan diharapkan dapat membantu melaksanakan kebijakan yang telah ditetapkan untuk mencapai tujuan yang telah direncanakan secara efektif dan efisien. Pengawasan juga dapat mendeteksi sejauhmana kebijakan Jaksa Agung menjalankan kewenangan dalam hal mengenyampingkan perkara demi kepentingan umum dan sampai sejauhmana penyimpangan yang terjadi dalam pelaksanaan tugas di bidang penuntutan tersebut.

Berfungsinya suatu pengawasan terhadap eksekutif yaitu Jaksa Agung akan sangat ditentukan oleh hukum tertinggi dari negara tersebut, yakni Konstitusi. Bagaimana konstitusi negara mengatur akan menentukan arah politik hukum negara yang bersangkutan. Konstisusi sebagai dasar politik hukum suatu negara didasarkan pada argumen bahwa konstitusi merupakan hukum dasar yang nerupakan hukum tertinggi dimana aturan yang dibawahnya harus bersumber pada konstitusi, sehingaa semua aturan tidak boleh bertentangan dengan konstitusi.

Begitu juga halnya pengawasan Deponering yang dikeluarkan oleh Jaksa Agung seharusnya selalu di awasi oleh lembaga peradilan dibawah Mahkamah Agung karena apabila kewenangan terkait pengenyampingan perkara demi kepentingan umum tidak diawasi akan menimbulkan potensi penyalahgunaan kekuasaan yang dilakakuan oleh Jaksa Agung yang dapat merugikan pihak korban yang merasa keberatan karena keputusan Deponering yang dikeluarkan oleh Jaksa Agung itu tidak memiliki Upaya Hukum karena bersifat Final.

Sebagai perbadingan dengan Kewenangan Jaksa Penuntut umum dalam mengeluarkan Surat Keputusan Penghentian Penuntutann (SKPP) dimana pihak yang merasa keberatan dengan surat ketetapan yang di keluarkan oleh Jaksa Penuntut Umum dapat melakukan Upaya Hukum yaitu Praperadilan. Dalam hal penuntut umum memutuskan untuk menghentikan penuntutan karena tidak terdapat cukup bukti atau peristiwa tersebut ternyata bukan merupakan tindak pidana atau perkara ditutup demi hukum, penuntut umum menuangkan hal tersebut dalam surat ketetapan. Hal inilah yang menyebabkan adanya perbedaan perlakuan dihadapan hukum dan tidak sesuai dengan salah satu asas negara hukum, yang dianut oleh negara Indonesia. serta bentuk upaya hukum yang dapat dilakukan dengan dikeluarkannya deponering ini.

Seharusnya dalam upaya pengawasan yang dilakukan oleh lembaga yudikatif terhadap kebijakan penegakan hukum di bidang penuntutan dalam hak pengenyampingan perkara demi kepentingan umum harus berjalan agar prinsip check and balance yang dianut di Indonesia, apabila suatu kewenangan 
Deponering tidak memiliki sebuah upaya hukum apapun hal ini tentunya akan betentangan dengan dasar negara yang menyatakan Indonesia adalah negara hukum (rechtstaat), karena kewenangan Deponering yang dimiliki oleh Jaksa Agung bersifat final dan tidak memiliki upaya hukum, hal itu tentu menjadikan negara Indonesia menjadi negara machtstaat (dimana kekuasaan penyelenggaraan negara berdasaran kekuasaan yang dimiliki oleh Jaksa Agung di bidang Penuntutan) karena disini juga Jaksa Agung dapat melihat suatu perkara bukan dari objek perkara tersebut tetapi dari subjek atau pelaku tindak pidana yang dimaksud seperti, Deponering yang banyak digunakan pada perkara perkara yang menjerat mantan Pemimpin KPK seperti Chandra M Hamzah dan Bibit S Riyanto (Bibit Candra) dan juga Bambang Wijayanto (BW) serta Abraham Samad. Yang juga dimana asas equality before the law yang menghendaki bahwa penuntut umum wajib menuntut semua perkara pidana yang terjadi tanpa memandang siapa dan bagaimana keadaan pelakunya ke muka sidang pengadilan tidak berjalan sesuai sebagaimana mestinya.

Untuk menjalankan Prinsip Check and Balance dimana kewenangan Jaksa Agung sebagai lembaga eksekutif dalam hal mengenyampingkan perkara demi kepentingan umum harus memiliki pengaturan mengenai upaya hukum sama seperti halnya SKPP, tujuannya tidak lain agar korban yang merasa dirugikan dengan adanya Ketetapan Deponering ini dapat mengajukan keberatan ke lingkup peradilan di bawah Mahkamah Agung yang sebagai lembaga yudikatif, tujuan lain untuk mengontrol keputusan Deponering yang dikeluarkan oleh Jaksa Agung apakah telah memenuhi unsur yang disebutkan dalam undang-undang kejaksaan mengenai kepentingan bangsa dan negara/atau kepentingan masyarakat luas dalam mengenyampingkan perkara demi kepentingan umum.

\section{KESIMPULAN}

1. Ratio Legis tidak adanya pengaturan terkait dengan upaya hukum ialah atas dasar pelaksaan Asas Opportunitas yang memberikan kebebasan yang sebebasbebasnya Jaksa Agung dalam hal mengenyampingkan perkara demi kepentingan umum. namun akibat dari kebebasan tersebut akan mudah untuk disalahgunakan dalam penerapan Deponering karena tidak memiliki kontrol pengawasan dari yudikatif.

2. Implikasi hukum tidak adanya pengaturan mengenai Upaya Hukum dari Deponering ini menimbulkan tidak berjalannya prinsip check and balance dan tidak berlakunya asas Equality Before The Law. Karena kewenangan Deponering yang dimiliki oleh Jaksa Agung bersifat final dan tidak memiliki upaya hukum, dan apabila kewenangan Jaksa Agung untuk mendeponir tidak dibatasi dan diawasi 
dikhawatirkan akan cenderung menyimpang dan menjadi penyalahgunaan wewenang oleh Jaksa Agung.

\section{DAFTAR PUSTAKA}

\section{Peraturan Perundang-undangan}

Undang-undang Dasar Negara Republik Indonesia Tahun 1945.

Undang-undang Nomor 15 Tahun 1961 Tentang Ketentuan-Ketentuan Pokok Kejaksaan Republik Indonesia.

Undang-undang Nomor 8 Tahun 1981 Tentang KUHAP.

Undang-undang Nomor 16 Tahun 2004 Tentang Kejaksaan Republik Indonesia.

Risalah Undang-undang Nomor 15 Tahun 1961 Tentamg Ketentuan-Ketentuan Pokok Kejaksaan Republik Indonesia.

Risalah Undang-undang Nomor 5 Tahun 1991 Tentang Kejaksaan Republik Indonesia.

Risalah Undang-undang Nomor 16 Tahum 2004 Tentamg Kejaksaan Republik Indonesia
Amiati Mia, 2014, Memaknaii Kepentingan Umum Dalam Oportunitas Jaksa Agung (Tinjauan Perspektif Teoretis), Jakarta, Miswar.

Kaligis O.C., 2011, Deponering, Teori dan Praktik, Bandung, Ed. Pertama Cetakan ke-1, PT. Alumni.

Manullang.M, 1995, Dasar-Dasar Manajemen, Jakarta, Ghalia Indonesia.

Marzuki Mahmud Peter, 2014, Penelitian Hukum, Jakarta, Kencana Prenada Media Group.

Nasution Karim, 2004, Dengar Pendapat Komisi III Dewan Perwakilan Rakyat Mengenai Masalah Hukum Acara Pidana, Jakarta.

Prakoso Djoko, 1985, Eksistensi Jaksa di Tengah-tengah Masyarakat, Jakarta, Ghlmia Indonesia.

\section{Internet}

https://nasional.kompas.com/read/2009/10/30 /20562153/inilah.kronologi.kasus.penyi dikan.kasus.chandra.dan.bibit diakses pada tanggal 15 Januari 2019 Pukul 16.00 WIB

\section{Buku}

